\title{
Mechanical Properties and Formaldehyde Release of Boards Manufactured with Hygrothermally Treated Tepa (Laureliopsis Philippiana Looser) Particles
}

\section{Mehanička svojstva i oslobađanje formaldehida ploča proizvedenih od hidrotermički obrađenog iverja drva tepe (Laureliopsis philippiana Looser)}

Original scientific paper • Izvorni znanstveni rad

Received-prispjelo: 3. 3. 2017.

Accepted-prihvaćeno: 23. 5. 2018.

UDK: $630 * 863.21$

doi:10.5552/drind.2018.1715

\begin{abstract}
Three layer particleboards were manufactured using hygrothermally treated and untreated tepa (Laureliopsis philippiana) particles with urea-formaldehyde (UF) resin. Hygrothermal treatment consisted of autoclaving particles at $150{ }^{\circ} \mathrm{C}$ for $90 \mathrm{~min}(430 \mathrm{kPa}$ ) in a steam saturated atmosphere. A decrease in density and slenderness ratio in treated particles was observed. Modulus of elasticity (MOE) and modulus of rupture (MOR) in static bending, internal bond (IB), and formaldehyde release were determined. An increase in MOE, MOR and $I B$, as well as a decrease in formaldehyde release, was reported in boards made from heat treated particles.
\end{abstract}

Key words: Particleboard, hygrothermal treatment, Laureliopsis philippiana, urea-formaldehyde, particle geometry, mechanical properties, formaldehyde release

SAŽETAK • Za potrebe ovog ispitivanja proizvedene su troslojne ploče iverice od neobrađenoga i hidrotermički obrađenog iverja drva tepe (Laureliopsis philippiana) primjenom urea-formaldehidnog (UF) ljepila. Hidrotermička se obrada sastojala od zagrijavanja iverja pri $150{ }^{\circ} \mathrm{C}$ tijekom 90 minuta u atmosferi zasićenoj vodenom parom (pri tlaku $430 \mathrm{kPa}$ ). Nakon hidrotermičke obrade čestica uočeno je smanjenje gustoće i vitkosti čestica. Troslojnim su pločama ivericama određeni modul elastičnosti (MOE) i modul loma (MOR) pri statičkom savijanju, čvrstoća raslo-

Author is professor at School of Forest Engineering, Faculty of Environmental Sciences, State Technical University of Quevedo, Quevedo, Ecuador. ${ }^{2}$ Author is professor at Department of Forest Management and Environment, Faculty of Forestry, University of Concepción, Concepción-Chile. ${ }^{3}$ Author is a Contract Auditor for APA (The Engineered Wood Association), Valdivia-Chile.

Autor je profesor Fakulteta znanosti o okolišu, Državno tehničko sveučilište u Quevedu, Quevedo, Ekvador. ${ }^{2}$ Autor je profesor Odjela za gospodarenje šumama i okolišem, Šumarski fakultet, Sveučilište u Concepciónu, Concepción, Čile. ${ }^{3}$ Autor je ugovorni revizor za APA-u (Društvo za obradu drva), Valdivia, Čile. 
javanja (IB) i količina oslobođenog formaldehida. Za ploče izrađene od toplinski obrađenih čestica zabilježeno je povećanje mehaničkih svojstava (MOE, MOR) i čvrstoće raslojavanja te smanjenje količine oslobođenog formaldehida.

Ključne riječi: ploča iverica, hidrotermička obrada, Laureliopsis philippiana, urea-formaldehid, geometrija čestica, mehanička svojstva, oslobođeni formaldehid

\section{INTRODUCTION}

\section{UVOD}

The production of boards with L. philippiana particles using UF as adhesive does not produce favourable results. If an excess of catalysts is not used, bonding failures are produced in the core of the board, leading to blowout (Poblete and Peredo, 1990; Pinto and Poblete, 1992). The high $\mathrm{pH}$ value of this species prevents proper hardening of the adhesive (Poblete, 2001). Thermal treatment using pressurized vapour results in the formation of organic acids that catalyze the hydrolysis of hemicellulose, and to a lesser extent, amorphous cellulose (Mitchell, 1988). The formation of acetic and formic acids at temperatures between 100 and $200{ }^{\circ} \mathrm{C}$ reduces the $\mathrm{pH}$ value of wood (Garrote $e t$ al., 1999; Nuopponen et al., 2004), encouraging the hardening of UF and improving mechanical properties.

The main objection to using thermally treated wood in the manufacturing of particleboards is the loss of mechanical strength. Paul and Ohlmeyer (2010) reported that the effects on the $M O E$ in the boards are negligible, while the effects on IB strength, and particularly on $M O R$, are higher.

\subsection{Effect of thermal treatment on mechanical} properties of the boards

1.1. Utjecaj toplinske obrade na mehanička svojstva ploča

Thermal treatment of particles produces a 20 to 25 $\%$ increase in bending strength in boards manufactured with UF (Tomek, 1966). However, it has also been reported that $M O E, M O R$ and density of thermally treated MDF decrease with increasing temperature (Ayrilmis et al., 2009). Water steam treatment of particles and fibers at temperatures over $200{ }^{\circ} \mathrm{C}$ may result in a reduction of the wood-adhesive adhesion (Boonstra et al., 2006), which reduces the IB of the boards (Mohebby et al., 2008, Ayrilmis et al., 2011), since thermal treatment may alter the adhesive distribution on the surface of the wood and the penetration within the porous structure of the wood (Sernek et al., 2008). Paul et al. (2007) state that wood, usually hydrophilic, becomes hydrophobic after thermal treatment. The loss of mechanical properties can be related to the formation of soluble chemical products by the degradation of hemicellulose, such as formic acid and acetic acid, which accelerate the depolymerisation of carbohydrates (Garrote et al., 2001; Sundqvist et al., 2006). The apparent contradictory results reported in the literature, may be because the thermal treatment of boards affects their whole structure and the interaction wood-adhesive-wood, degrading the adhesive bonds. Other important aspects are the temperature and conditions of thermal treatment employed. When high temperatures and pressures were employed, a higher degradation of the wood components is caused, reducing the mechanical properties.

\subsection{Effect of thermal treatment on formaldehyde} release

1.2. Utjecaj toplinske obrade na oslobađanje formaldehida

Roffael (2012) reported that, when defibration temperature is increased, it results in acidification of fibres and a reduction in the release of formaldehyde from MDF. Petersen et al. (1973) reported that particleboards manufactured from wood with low $\mathrm{pH}$ value emit lower quantities of formaldehyde than boards manufactured from wood with greater $\mathrm{pH}$ value.

\subsection{Objectives}

1.3. Ciljevi

The main objective of this study was to determine the effect of a hygrothermal treatment in steam saturated atmosphere on L. philippiana particles and the implications on properties of three layer particleboards. Specific objectives included the study of changes in particle geometry that can take place during gluing process. In particleboards, changes of $M O E$ and $M O R$ in static bending, IB, and formaldehyde release were determined.

\section{MATERIALS AND METHODS}

2. MATERIJALI I METODE

\subsection{Particles production and hygrothermal treatment}

2.1. Proizvodnja iverja i hidrotermička obrada

L. philippiana wood was harvested from the XIV Region de Los Ríos near to the Andean mountains in Chile. The wood was cut into shavings and then, using a Pallmann PZ2 mill, particles were obtained. A quantity of the particles was treated in the autoclave at $150{ }^{\circ} \mathrm{C}$ for 90 min at $430 \mathrm{kPa}$ pressure, in a steam saturated atmosphere.

\subsection{Drying of particles}

2.2. Sušenje iverja

Hygrothermally treated and non-treated particles were subjected to a drying process, in a Heraeus particle dryer with air circulation at $70^{\circ} \mathrm{C}$, until a moisture content of $4 \%$ was reached.

\subsection{Particle properties: dimensions, slenderness ratio, specific surface area and available} adhesive quantity

2.3. Svojstva čestica: dimenzije, vitkost, specifična površina i raspoloživa količina ljepila

In order to quantify changes caused by the treatment, particles were subjected to the mechanical action of the blender without adhesive. After this procedure, $120 \mathrm{~g}$ of particles were sieved in a Retsch sieving machine using mesh size of 4.0, 2.8, 2.0, 1.4, 1.0, 0.5 and $<0.5 \mathrm{~mm}$. Each particle class was weighed to determine the proportional participation. In 30 particles of every class, length and thickness were determined using a micrometer and caliper. Basic density of the par- 
ticles according to TAPPI T 258 om-94 was calculated. With the particle length, thickness and density data, slenderness ratio (Poblete and Peredo, 1990), specific surface area and available adhesive quantity (Poblete, 2001) were determined by the formulae:

$\begin{aligned} & \text { Specific } \\ & \text { surface area } \\ & \left(\mathrm{m}^{2} / 100 \mathrm{~g}\right)\end{aligned}$
$\begin{aligned} & \begin{array}{l}\text { Avaliable } \\ \text { adhesive } \\ \left(\mathrm{g} / \mathrm{m}^{2}\right)\end{array} \\ & \text { Thickness }(\mathrm{mm}) \times \text { Density }\left(\mathrm{g} / \mathrm{cm}^{3}\right)\end{aligned}$
$\begin{gathered}\text { Density }\left(\mathrm{g} / \mathrm{cm}^{3}\right) \times \text { Thickness }(\mathrm{mm}) \\ x \text { Gluing factor }(\%)\end{gathered}$

\subsection{Board manufacturing}

2.4. Proizvodnja ploča

Hygrothermally treated and untreated L. philippiana particles were employed. The percentage of wood in the outer layer was $30 \%$ and in the inner layer $70 \%$. UF (50\% solid) produced by Georgia Pacific Corp. with a molar ratio of 1:1.22 was applied as adhesive. This is a high emission resin, and was used without formaldehyde scavenger and without hardener in order to best determine the variation in formaldehyde release due to hygrothermal treatment. Particleboards with nominal densities of $600,625,650,675$ and $700 \mathrm{~kg} \cdot \mathrm{m}^{-3}$, with dimensions of $53 \times 53 \mathrm{~cm}$ and $15 \mathrm{~mm}$ thickness were produced. The adhesive was applied at $8 \%$ loading (dry basis) spraying it in a Drais FSP-80 blender. Pressing was conducted in a Bürkle LA-160 press at a temperature of $180{ }^{\circ} \mathrm{C}$ for $180 \mathrm{~s}$. The maximum pressure used was $3 \mathrm{~N} \cdot \mathrm{mm}^{-2}$ for $30 \mathrm{~s}$ and half pressure of $1.5 \mathrm{~N} \cdot \mathrm{mm}^{-2}$ for $150 \mathrm{~s}$. Two boards were produced for each nominal density, a total of 10 boards with non-treated particles and 10 boards with treated particles.

\subsection{Mechanical properties of the boards}

2.5. Mehanička svojstva ploča

Density (EN 323, 1993), MOE and MOR in static bending (EN 310, 1993), and $I B$ (EN 319, 1993) were determined. The mechanical properties were carried out in a Metrotec HM-D/200 universal testing machine. The rate of loading was adjusted so that the maximum load was reached within $60 \pm 30 \mathrm{~s}$. The number of test specimens by treatment obtained in all board series for static bending ( $M O E$ and $M O R$ ) was 100 and for IB 90. The density was determined for every test specimen.

\subsection{Formaldehyde release}

\subsection{Oslobođeni formaldehid}

This was conducted according to the perforator method (EN 120, 1992). Three samples of the average nominal board density were analysed.

The perforator value was corrected in accordance with EN 312 (2010).

\subsection{Statistical analysis \\ 2.7. Statistička analiza}

A simple linear regression analysis was conducted, relating each mechanical property to the density of the respective test specimen. Additionally, an analysis of variance was conducted with a $99 \%$ confidence interval $(p<0.01)$ (statistical program $R$ ), to determine differences among averages of properties. In the case of formaldehyde release determinations, because of the amount of tests, no statistical analysis was done, and for the results and discussion, the average of the three tests was considered.

\section{RESULTS AND DISCUSSION}

\section{REZULTATI I RASPRAVA}

\subsection{Particle geometry, specific surface area and} quantity of available adhesive

3.1. Geometrija čestica, specifična površina i količina raspoloživog ljepila

The change of the particles geometry comes along with a change in the slenderness ratio, specific surface area and available amount of adhesive. This modification of the geometry could have an effect on panel properties. As reported by Klauditz (Ginzel and Peraza, 1966) for the determination of the slenderness ratio, specific surface area of the particles and the available amount of adhesive, it is necessary to characterize the particles through the determination of basic density, thickness and length. The average weighted in accordance to the weight proportion of the particles in each sieve mesh for hygrothermally treated and untreated particles is presented in Table 1.

Table 1 Basic density, thickness, length, slenderness ratio, specific surface area and amount of available adhesive for hygrothermally treated and untreated L. philippiana particles

Tablica 1. Nominalna gustoća, debljina, duljina, vitkost, specifična površina i količina raspoloživog ljepila za hidrotermički obrađeno i neobrađeno iverje drva L. philippiana

\begin{tabular}{|l|l|c|c|c|c|c|c|}
\hline \multicolumn{2}{|c|}{$\begin{array}{c}\text { Particles } \\
\text { Iverje }\end{array}$} & $\begin{array}{c}\text { Basic } \\
\text { density } \\
\text { Nominalna } \\
\text { gustoća } \\
\mathrm{kg} \cdot \mathrm{m}^{3}\end{array}$ & $\begin{array}{c}\text { Thickness } \\
\text { Debljina }\end{array}$ & $\begin{array}{c}\text { Length } \\
\text { Duljina }\end{array}$ & $\begin{array}{c}\text { Slenderness } \\
\text { Ratio } \\
\text { Vitkost iverja }\end{array}$ & $\begin{array}{c}\text { Specific } \\
\text { surface area } \\
\text { Specifična } \\
\text { površina } \\
\mathrm{m}^{2} / 100 \mathrm{~g}\end{array}$ & $\begin{array}{c}\text { Available } \\
\text { adhesive } \\
\text { Raspoloživo } \\
\text { ljepilo } \\
\mathrm{g} / \mathrm{m}^{2}\end{array}$ \\
\hline $\begin{array}{l}\text { Surface } \\
\text { Layer } \\
\text { Vanjski } \\
\text { sloj }\end{array}$ & $\begin{array}{l}\text { Untreated } \\
\text { neobrađeno }\end{array}$ & 442 & 0.63 & 6.75 & 11.19 & 0.72 & 11.18 \\
\hline $\begin{array}{l}\text { Thermally treated } \\
\text { termički obrađeno }\end{array}$ & 428 & 0.60 & 6.48 & 10.85 & 0.78 & 10.25 \\
\hline $\begin{array}{l}\text { Layer } \\
\text { Unutarnji } \\
\text { sloj }\end{array}$ & $\begin{array}{l}\text { Untreated } \\
\text { neobrađeno }\end{array}$ & 442 & 0.90 & 14.55 & 16.00 & 0.50 & 15.98 \\
\cline { 2 - 9 } & $\begin{array}{l}\text { Thermally treated } \\
\text { termički obrađeno }\end{array}$ & 428 & 0.88 & 13.80 & 15.75 & 0.53 & 15.12 \\
\hline
\end{tabular}


Table 2 Analysis of variance of the mean values of mechanical properties of boards manufactured with hygrothermally treated and untreated L. philippiana particles

Tablica 2. Analiza varijance vrijednosti mehaničkih svojstava ploča proizvedenih od hidrotermički obrađenoga i neobrađenog iverja drva L. philippiana

\begin{tabular}{|c|c|c|c|c|c|c|c|}
\hline \multirow{3}{*}{$\begin{array}{l}\text { Mechanical property } \\
\text { Mehaničko svojstvo }\end{array}$} & \multicolumn{7}{|c|}{ Analysis of variance / Analiza varijance } \\
\hline & \multicolumn{3}{|c|}{ Untreated / Neobrađeno } & \multicolumn{3}{|c|}{$\begin{array}{l}\text { Hygrothermally treated } \\
\text { Hidrotermički obrađeno }\end{array}$} & \multirow{2}{*}{$p$-value } \\
\hline & $\begin{array}{c}\bar{x} \\
\mathrm{~N} \cdot \mathrm{mm}^{-2}\end{array}$ & $\begin{array}{c}\boldsymbol{s} \boldsymbol{d} \\
\mathrm{N} \cdot \mathrm{mm}^{-2}\end{array}$ & $\begin{array}{l}\mathrm{cV} \\
\%\end{array}$ & $\begin{array}{c}\bar{x} \\
\mathrm{~N} \cdot \mathrm{mm}^{-2}\end{array}$ & $\begin{array}{c}\boldsymbol{s} \boldsymbol{d} \\
\mathrm{N} \cdot \mathrm{mm}^{-2}\end{array}$ & $\begin{array}{l}\text { cv } \\
\%\end{array}$ & \\
\hline$M O E$ in static bending / MOE pri statičkom savijanju & 2023 & 386.5 & 19.11 & 3285 & 457.4 & 45.28 & $0.000^{*}$ \\
\hline MOR in static bending / MOR pri statičkom savijanju & 12.62 & 3.07 & 24.34 & 20.03 & 3.81 & 19.00 & $0.000^{*}$ \\
\hline IB & 0.24 & 0.18 & 76.41 & 0.47 & 0.15 & 31.39 & $0.000^{*}$ \\
\hline
\end{tabular}

$\bar{x}$ - mean / srednja vrijednost; sd - standard deviation / standardna devijacija; cv - coefficient of variation / koeficijent varijacije; ${ }^{*}$ - Significant at $p<0.01 /$ signifikantno pri $p<0,01$.

The results of hygrothermal treatment showed a decrease in the basic density of particles. As a consequence, thermally untreated particles presented a larger quantity of available adhesive, as total grams of adhesive per surface, square meter of particles. The decrease in the basic density of particles agrees with the decrease in density reported by other investigators (Schmidt, 1982; Feist and Sell, 1987). This effect is due to the thermal degradation of wood components, such as deacetylation of hemicellulose and lignin condensation, and to the lower equilibrium moisture content, since thermally treated wood becomes hydrophobic (Boonstra et al., 2007).

Thickness and specific surface area of the particles did not change. Length, and hence slenderness ratio, decreased. This decrease was more significant in larger particles. Generally, it can be concluded that during the mechanical action of the gluing machine, it is the larger particles that undergo a reduction in size. The decrease in length of the particles may cause a change in the me- chanical properties of the boards, causing a reduction of $M O E$ and $M O R$, and increasing IB.

\subsection{Mechanical properties of the boards \\ 3.2. Mehanička svojstva ploča}

Table 2 shows the averages, standard deviation, coefficient of variation and $p$ values, according to the analysis of variance for boards manufactured with hygrothermally treated and untreated particles. The mechanical properties of the boards manufactured with hygrothermally treated and untreated particles present significant differences $(p<0.01)$. The strength of the boards in static bending is correlated with the quality of the bonds achieved on the surface of the boards (Poblete, 2001).

The linear regression analysis registered significance at $p<0.01$. Coinciding with previous studies, when the density of the boards increased, the $M O E$ and MOR also increased (Poblete, 2001). The regression analysis for the relationship between density and $M O E$

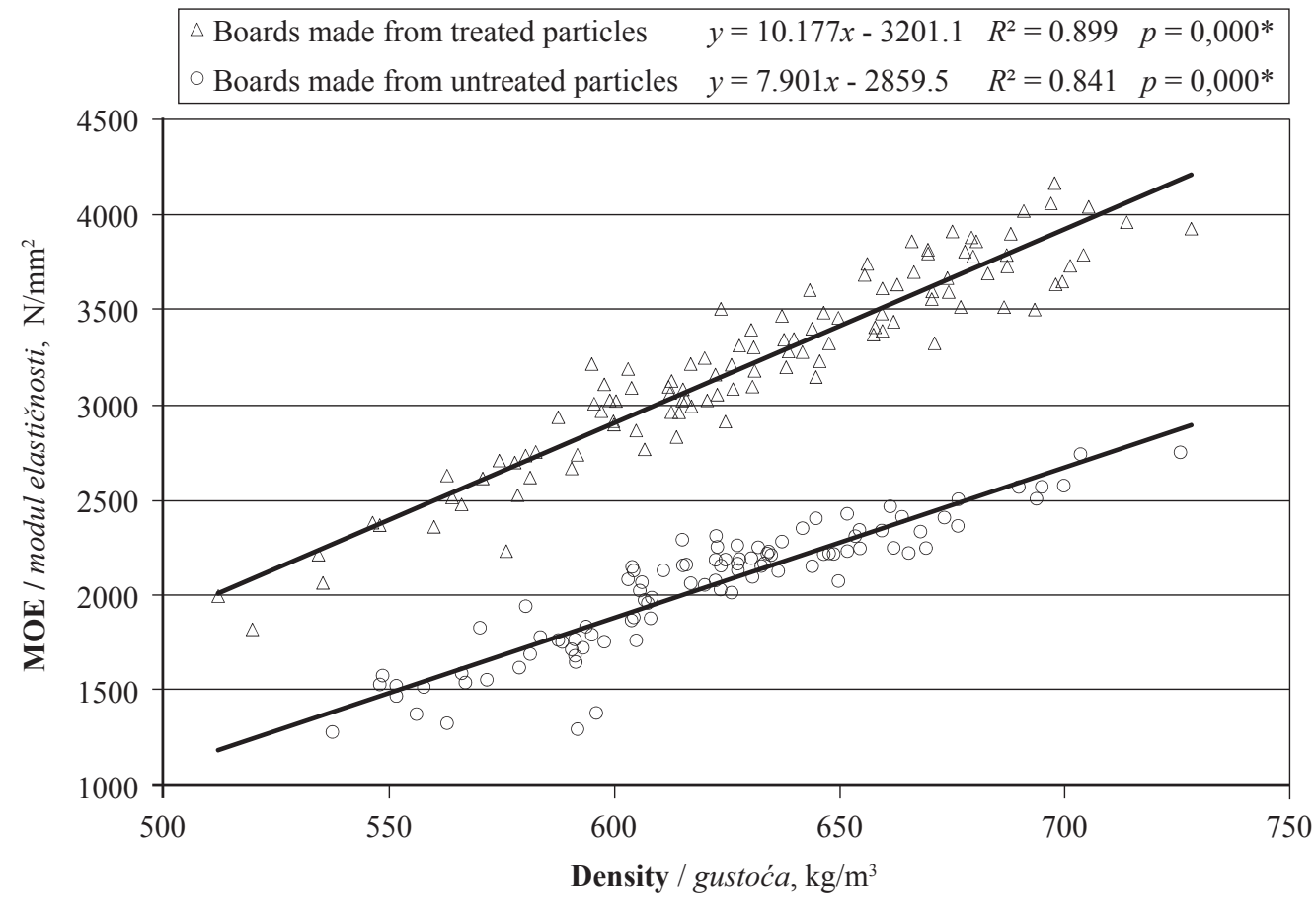

Figure 1 Relationship between $M O E$ and density in L. philippiana boards manufactured with hygrothermally treated and untreated particles

Slika 1. Odnos modula elastičnosti i gustoće ploča proizvedenih od hidrotermički obrađenoga i neobrađenog iverja drva $L$. philippiana 


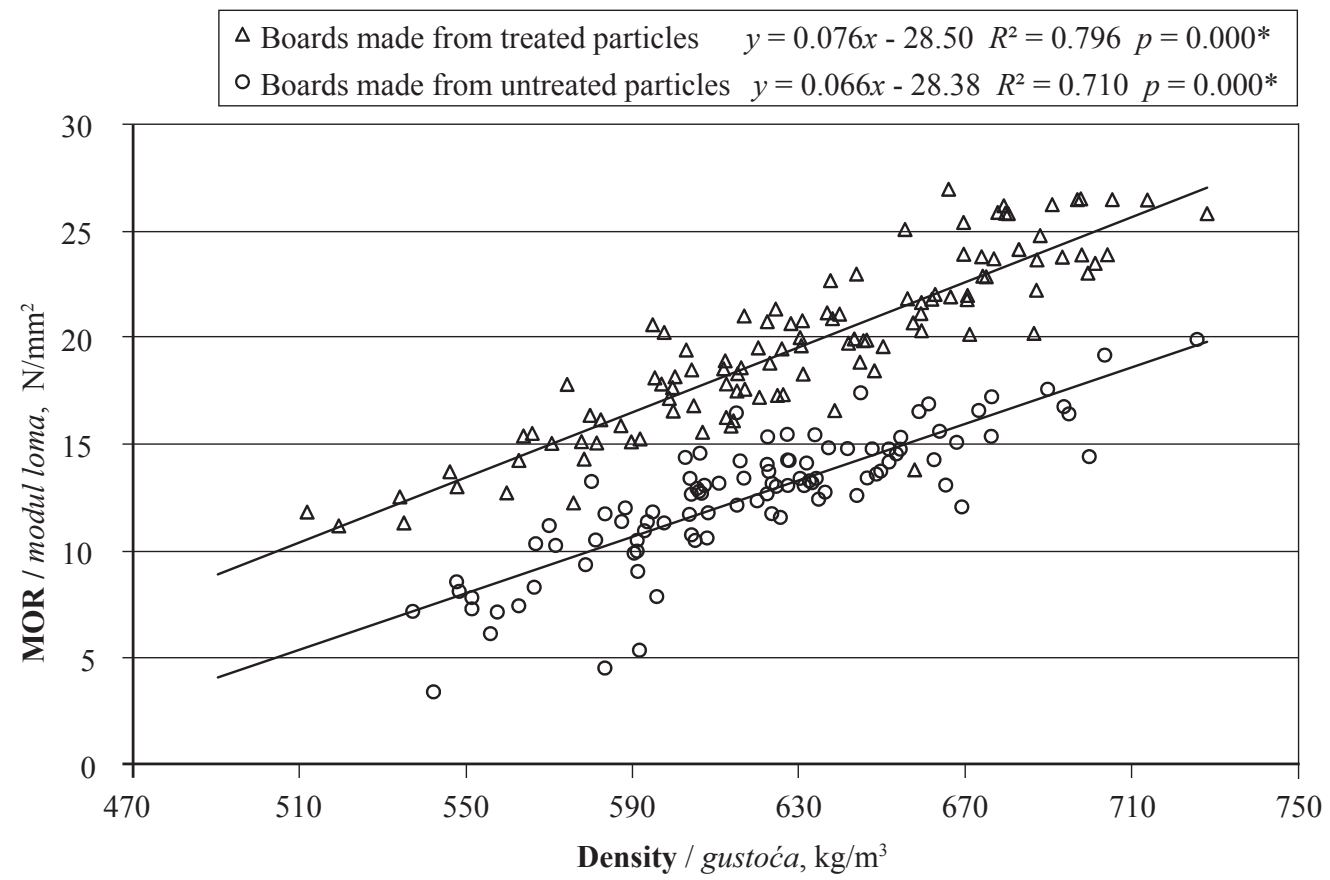

Figure 2 Relationship between MOR and density in L. philippiana boards manufactured with hygrothermally treated and untreated particles

Slika 2. Odnos modula loma i gustoće ploča proizvedenih od hidrotermički obrađenoga i neobrađenog iverja drva $L$. philippiana

is shown in Figure 1, and the relationship between density and MOR in Figure 2.

The regression for the relationship between density and $I B$ is presented in Figure 3. Correlations were significant at $p<0.01$. $I B$ is directly related with the bond quality of the particles in the core of the board (Poblete and Burgos, 2010). The results confirm the strong relationship between board density and $I B$, reported in many studies (Kollmann et al., 1975; Poblete, 1985; Poblete, 2001; Poblete and Burgos, 2010).

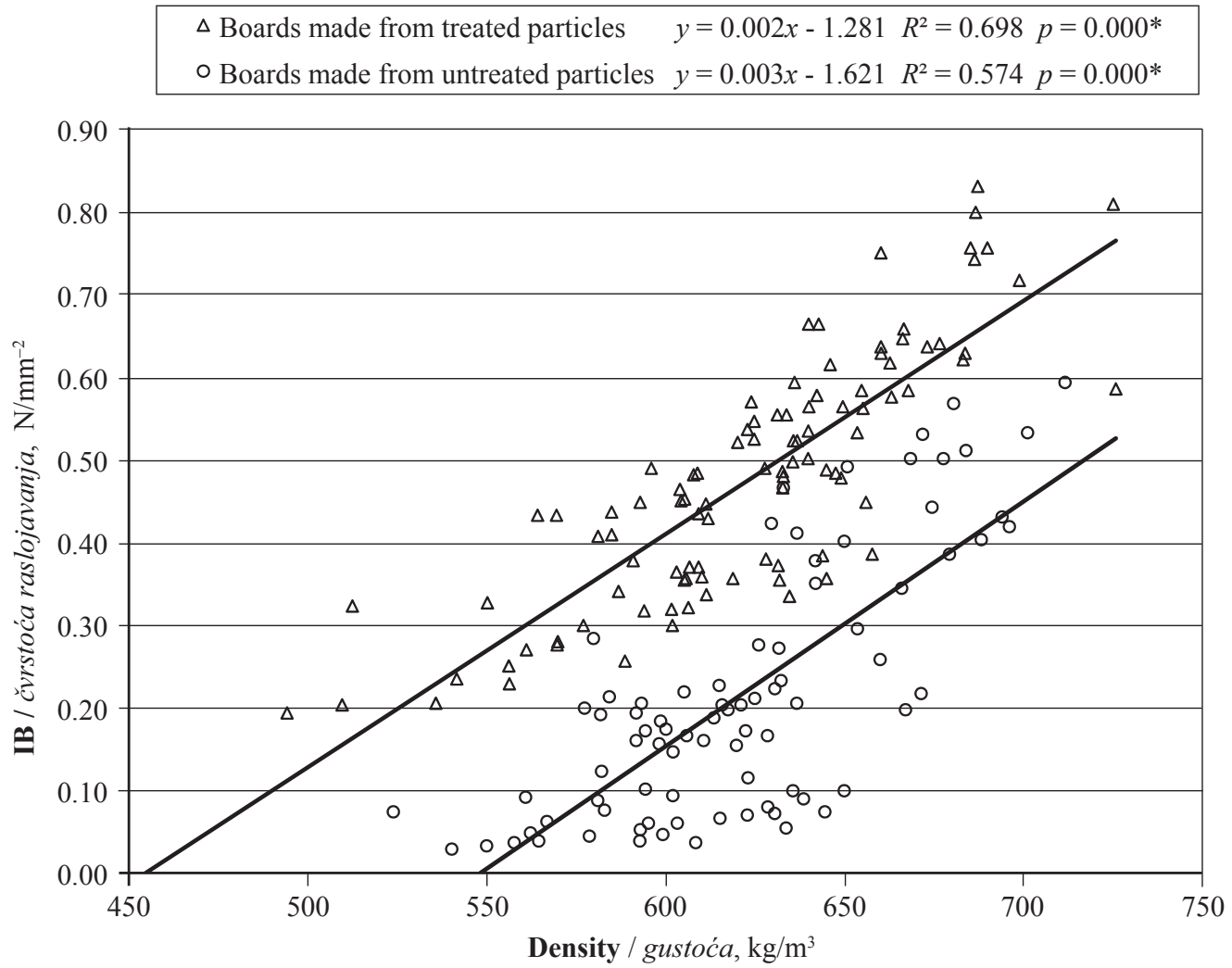

Figure 3 Relationship between density and $I B$ of $L$. philippiana boards manufactured with hygrothermally treated and untreated particles

Slika 3. Odnos gustoće i čvrstoće raslojavanja ploča proizvedenih od hidrotermički obrađenoga i neobrađenog iverja drva $L$. philippiana 
Table 3 Formaldehyde release average with and without moisture content correction

Tablica 3. Prosječna vrijednost oslobođenog formaldehida s korekcijom sadržaja vode i bez korekcije

\begin{tabular}{|c|c|c|c|}
\hline \multirow{2}{*}{$\begin{array}{l}\text { Particles } \\
\text { Iverje }\end{array}$} & \multirow{2}{*}{$\begin{array}{c}\text { Equilibrium moisture } \\
\text { content } \\
\text { Ravnotežni sadržaj vode } \\
\%\end{array}$} & \multicolumn{2}{|c|}{$\begin{array}{l}\text { Formaldehyde release / Oslobođeni formaldehid } \\
\text { mg/100 g }\end{array}$} \\
\hline & & $\begin{array}{c}\text { Uncorrected value } \\
\text { Nekorigirana vrijednost }\end{array}$ & $\begin{array}{c}\text { Corrected value } \\
\text { Korigirana vrijednost }\end{array}$ \\
\hline Untreated / Neobrađeno & 8.2 & 17.1 & 13.2 \\
\hline Thermally treated / Toplinski obrađeno & 6.2 & 9.8 & 10.1 \\
\hline
\end{tabular}

According to the analysis of variance, boards manufactured with treated L. philippiana particles presented better mechanical properties. In the static bending, the $M O E$ increased by $38.4 \%$, while the $M O R$ increased by $37.0 \%$. IB increased by $48.9 \%$. The increase in $M O E, M O R$ and $I B$ is in agreement with values reported by other studies (Tomek, 1966; Kakaras and Papadopoulos, 2004; Çolak et al., 2007). When determining mechanical properties of particleboards, the wood-adhesive-wood interaction is evaluated, which is influenced by the type of adhesive and the environment in which it hardens. The $\mathrm{pH}$ value is what determines the success or failure of the bond. In a previous work about the effect of hygrothermal treatment on the chemistry of the same L. philippiana particles (Crespo et al., 2013), a pH value of non-treated particles near neutral (6.7) was reported. This condition could inhibit UF curing if a hardener is not used. It should be noted that in this study a hardener was not applied. Pinto and Poblete (1992) studied L. philippiana particles, and acidified the environment with the addition of a catalyst, with positive effects on mechanical properties.

Çolak et al. (2007) have confirmed that the $\mathrm{pH}$ values of the particles obtained from vaporized logs decrease, generating an optimum $\mathrm{pH}$ environment during the curing of UF, and increasing the IB of the boards. Crespo et al. (2013) reported for the same $L$. philippiana particles that hygrothermal treatment decreased the $\mathrm{pH}$ value from 6.7 to 4.8 , while the quantity of volatile acids, water soluble acids and buffering capacity, increased. These changes allow for better hardening of UF and a better wood-adhesive-wood bond, which explains the increase in bending strength properties and IB in the tested boards (Roffael and Parameswaran, 1986; Roffael, 1987).

The decrease in length and slenderness ratio in thermally treated particles observed in the current study may have also influenced the increase in IB of the boards. Coincidentally, Kakaras and Papadopoulos (2004) reported that treated particles produced an increase in the proportion of smaller particles, which is associated with an increase in IB. In the current study, considering that $M O E$ and $M O R$ increased, the contribution of the particles size reduction to the increase of IB is less than the change in acidity.

\subsection{Formaldehyde release}

\subsection{Oslobađanje formaldehida}

Table 3 shows the average values of formaldehyde release (perforator value) with and without moisture content correction.
The equilibrium moisture of the boards following acclimatization was different, and according to the standard (EN 312, 2010), the release value should be adjusted considering this parameter. Determinations with and without moisture content adjustments show that the hygrothermal treatment decreased the release of formaldehyde. Giebeler (1983) confirmed that, after the treatment of wood with moisture, heat and pressure, the most important improvement is the decrease by over $50 \%$ in formaldehyde release of particleboards. Petersen et al. (1973) reported that boards manufactured from species with lower $\mathrm{pH}$ values (3.8) released less formaldehyde than boards made from species with higher $\mathrm{pH}$ values (4.8 and 5.5). There was no correction by moisture content of the boards reported in either of these studies. The results of Petersen et al. (1973) support that the decrease in the $\mathrm{pH}$ value of hygrothermally treated particles of L. Philippiana, which was reported by Crespo et al. (2013) in a former study, reduce the formaldehyde release of boards made from these particles.

Roffael (2012) reported that, when working with MDF manufactured with UF, an increase in defibration temperature from 140 to $175^{\circ} \mathrm{C}$ results in a positive effect on formaldehyde release, which is attributed to the higher acidity of the thermo-mechanical pulp produced at $170{ }^{\circ} \mathrm{C}$. Colak and Colakoglu (2004) claim that the acetic acid generated from the hydrolysis of non-cellulose polysaccharide acetyl groups reacts with the free formaldehyde in the resin, fixing this compound. As reported by Crespo et al. (2013) in a former study with the same particles of L. philippiana, hygrothermal treatment of particles increases the amount of volatile acids, water soluble acids and buffering capacity, significantly reducing the $\mathrm{pH}$ value. Considering the results of the current study, it can be confirmed that the reduction in formaldehyde release in boards manufactured with hygrothermally treated particles is due to the reduction in $\mathrm{pH}$ value, to the production of acids, and consequently to better setting of the UF.

\section{CONCLUSIONS}

\section{ZAKLJUČAK}

Hygrothermal treatment of L. philippiana wood particles resulted in lower basic density, length, slenderness ratio and quantity of available adhesive, while the specific surface area increased relative to untreated particles. The hygrothermal treatment increases mechanical properties in particleboards, while decreasing formaldehyde release. This effect is due to an acidification of the particles and an increase in the amount of 
extractable compounds. Overall, hygrothermal treatment of L. philippiana particles at $150{ }^{\circ} \mathrm{C}$ for $90 \mathrm{~min}$ at the pressure of $430 \mathrm{kPa}$ is a good alternative to improve mechanical properties, as well as to reduce formaldehyde release in particle boards manufactured from this species.

\section{Acknowledments - Zahvala}

This study was supported by a scholarship from the Comisión Nacional de Investigación Científica y Tecnológica (CONICYT) from Chile, and by the Secretaría de Educación Superior, Ciencia, Tecnología e Innovación (SENESCYT) from Ecuador.

\section{REFERENCES}

6. LITERATURA

1. Ayrilmis, N.; Laufenberg, T.; Winandy, J., 2009: Dimensional stability and creep behavior of heat-treated exterior medium density fiberboard. European Journal of Wood and Wood Products, 67 (3): 287-295. https://doi.org/10.1007/s00107-009-0311-7

2. Ayrilmis, N.; Jarusombuti, S.; Fueangvivat, V.; Bauchongkol, P., 2011: Effects of thermal treatment of rubberwood fibres on physical and mechanical properties of medium density fibreboard. Journal of Tropical Forest Science, 23 (1): 10-16.

3. Boonstra, M.; Pizzi, A.; Zomers, F.; Ohlmeyer, M.; Paul, W., 2006: The effects of two stage heat treatment process on the properties of particleboard. Holz als Roh- und Werkstoff, 64 (2): 157-164.

https://doi.org/10.1007/s00107-005-0055-y.

4. Boonstra, M.; Van Acker, J.; Tjeerdsma, B.; Kegel, E., 2007: Strength properties of thermally modified softwoods and its relation to polymeric structural wood constituents. Annals of Forest Science, 64 (7): 679-690. https://doi.org/10.1051/forest:2007048

5. Colak, S.; Colakoglu, G., 2004: Volatile acetic acid and formaldehyde emission from plywood treated with boron compound. Building and Environment, 39 (5): 533-536. https://doi.org/10.1016/j.buildenv.2003.08.019.

6. Çolak, S.; Çolakoğlu, G.; Aydin, I.; Kalaycioğlu, H., 2007: Effects of steaming process on some properties of eucalyptus particleboard bonded with UF and MUF adhesives. Building and Environment, 42 (1): 304-309. https://doi.org/10.1016/j.buildenv.2005.08.013.

7. Crespo, R.; Torres, M.; Valenzuela, L.; Poblete, H., 2013: Propiedades químicas, color y humectabilidad de partículas de Laureliopsis philippiana (tepa) con y sin tratamiento térmico. Maderas. Ciencia y tecnología, 15 (3): $337-348$

https://doi.org/10.4067/S0718-221X2013005000026.

8. EN 120. 1992: Wood based panels. Determination of formaldehyde content. Extraction method called the perforator method. European Committee for Standardization. Brussels, Belgium. 10 p.

9. EN 310. 1993: Wood-based panels. Determination of modulus of elasticity in bending and of bending strength. European Committee for Standardization. Brussels, Belgium. $8 \mathrm{p}$.

10. EN 312. 2010: Particleboards - Specifications. European Committee for Standardization. Brussels, Belgium. 22 p.

11. EN 319. 1993: Particleboards and fibreboards. Determination of the tensile strength perpendicular to the plane of the board. European Committee for Standardization. Brussels, Belgium. 6 p.
12. EN 323. 1993: Wood based panels. Determination of density. European Committee for Standardization. Brussels, Belgium. 5 p.

13. Feist, W.; Sell, J., 1987: Weathering behavior of dimensionally stabilized wood treated by heating under pressure of nitrogen gas. Wood and Fiber Science, 19 (2): 183-195.

14. Garrote, G.; Domínguez, H.; Parajó, A., 1999: Hydrothermal processing of lignocellulosic materials. Holz als Roh- und Werkstoff, 57 (3): 191-202. https://doi.org/10.1007/s001070050039.

15. Garrote, G.; Domínguez, H.; Pajaró, J., 2001: Study on deacetylation of hemicelluloses during the hydrothermal processing of Eucalyptus wood. Holz als Roh- und Werkstoff, 59 (1-2): 53-59.

https://doi.org/10.1007/s001070050473.

16. Giebeler, E., 1983: Dimensionsstabilisierung von Holz durch eine Feuchte/Wärme/Druck-Behandlung. Holz als Roh- und Werkstoff 41 (3): 87-94. https://doi.org/10.1007/BF02608498.

17. Ginzel, W.; Peraza, C. 1966: Tecnología de tableros de partículas. Instituto de Investigaciones y Experiencias. Ministerio de Agricultura. Madrid, España. 185 p.

18. Kakaras, I.; Papadopoulos, A., 2004: The effects of drying temperature of wood chips upon the internal bond strength of particleboard. Journal of the Institute of Wood Science, 16 (5): 277-279.

19. Kollmann, F.; Kuenzi, E.; Stamm, A., 1975. Principles of Wood Science and Technology. II. Wood Based Materials. Springer Verlag. Berlin, Germany. 703 p. https://doi.org/10.1007/978-3-642-87931-9

20. Mitchell, P., 1988: Irreversible property changes of small loblolly pine specimens heated in air, nitrogen, or oxygen. Wood and Fiber Science, 20 (3): 320-355.

21. Mohebby, B.; Ilbeighi, F.; Kazemi-Najafi, S., 2008: Influence of hydrothermal modification of fibers on some physical and mechanical properties of medium density fiberboard (MDF). Holz als Roh- und Werkstoff, 66 (3): 213-218. https://doi.org/10.1007/s00107-008-0231-y.

22. Niemz, P.; Poblete, H.; Torres, M.; Ugalde, G., 2005: Untersuchungen zur thermischen und hydrothermischen Behandlung von Eucalyptus nitens. Holz, 1 (2): 12-16.

23. Nuopponen, M.; Vuorinen, T.; Jamsä, S.; Viitaniemi, P., 2004: Thermal modifications in softwood studied by FTIR and UV resonance Raman spectroscopies. Journal of Wood Chemistry and Technology, 24 (1): 13-26. https://doi.org/10.1081/WCT-120035941.

24. Paul, W.; Ohlmeyer, M.; Leithoff, H., 2007: Thermal modification of OSB-strands by a one-step heat pre treatment-Influence of temperature on weight loss, hygroscopicity and improved fungal resistance. Holz als Roh- und Werkstoff, 65 (1): 57-63. https://doi.org/10.1007/s00107-006-0146-4.

25. Paul, W.; Ohlmeyer, M. 2010: Thermally and Chemically Modified Wood-Based Panels. Chapter 8. In: Thoemen, H.; Mark, I.; Sernek, M. (eds.). Wood-Based Panels: An Introduction for Specialists. Brunel University Press. London, England. 304 p.

26. Petersen, H.; Reuther, W.; Eisele, W.; Wittmann, O., 1973: Zur Formaldehydabspaltung bei der Spanplattenerzeugung mit Harnstoff-Formaldehyd-Bindemitteln. Zweite Mitteilung: Der Einfluß von Festharzmenge, Presszeit und Presstemperatur. Holz als Roh- und Wersktoff, 31 (12): 465-469. https://doi.org/10.1007/BF02613831.

27. Pinto, A.; Poblete, H., 1992: Efecto del catalizador en las propiedades de tableros de partículas con madera de tepa. Ciencia e Investigación Forestal, 6 (2): 259-279. 
28. Poblete, H. 1985. Influencia del tamaño de la partícula sobre las propiedades mecánicas flexión y tracción en tableros de partículas aglomerados con ureaformaldehído. Universidad Austral de Chile. En: Pinus radiata Investigación en Chile. Pp. 241-256.

29. Poblete, H.; Peredo, M., 1990: Tableros de desechos del debobinado de especies chilenas. Bosque, 11 (2): 45-58. https://doi.org/10.4206/bosque.1990.v11n2-05

30. Poblete, H., 2001: Tableros de partículas. Universidad Austral de Chile. Facultad de Ciencias Forestales. Editorial El Kultrún. Valdivia, Chile. 177 p.

31. Poblete, H.; Burgos, R., 2010: Eucalyptus nitens como materia prima para tableros de partículas. Maderas. Ciencia y tecnología, 12 (1): 25-35. https://doi.org/10.4067/S0718-221X2010000100003.

32. R Core Team. 2014: R: A language and environment for statistical computing. R Foundation for Statistical Computing, Vienna, Austria. URL http://www.R-project.org/.

33. Roffael, E.; Parameswaran, N., 1986: Einfluß der latenten Acidität in Buchenholzspänen auf deren Verleimbarkeit mit Harnstoff-Formaldehydharzen. Holz als Rohund Werkstoff, 44 (10): 389-393. https://doi.org/10.1007/ BF02615191.

34. Roffael, E. 1987: Drying of pine particles and the effect on the strength of particleboard. In: Proceedings $21^{\text {st }} \mathrm{In}$ ternational Particleboard/Composite Materials Symposium. Washington State University. Pullman, Washington, United States. Pp. 361-381.

35. Roffael, E., 2012: Influence of resin content and pulping temperature on the formaldehyde release from medium density fibreboards (MDF). European Journal of Wood and Wood Products, 70 (5): 651-654. https://doi.org/10.1007/s00107-012-0614-y.
36. Schmidt, K., 1982: Auswirkungen verschiedener Parameter beim Dämpfen von Rotbuchenholz, 2. Teil Feuchtigkeitsaufnahme während des Dämpfens. Holzforschung und Holzverwertung, 34 (4): 65-69.

37. Sernek, M.; Boonstra, M.; Pizzi, A.; Despres, A.; Gérardin, P., 2008: Bonding performance of heat treated wood with structural adhesives. Holz als Roh- und Werkstoff, 66 (3): 173-180. https://doi.org/10.1007/s00107-007-0218-0.

38. Sundqvist, B.; Karlsson, O.; Westermark, U., 2006: Determination of formic-acid and acetic acid concentrations formed during hydrothermal treatment of birch wood and its relation to colour, strength and hardness. Wood Science and Technology, 40 (7): 549-561. https://doi.org/10.1007/s00226-006-0071-z.

39. Tomek, A., 1966: Die Heißvergütung von Holzspänen, ein neues Verfahren zum Hydrophobieren von Spanplatten. Holztechnologie, 7 (3): 157-160.

40. *** 1994: TAPPI T $258 \mathrm{om}$. Basic density and moisture content of pulpwood. In: Technical Association of the Pulp and Paper Industry (TAPPI). Test Methods $2000-$ 2001. TAPPI Press. Atlanta, United States.

\section{Corresponding address:}

Prof. ROMMEL CRESPO, Ph.D.

Universidad Técnica Estatal de Quevedo QUEVEDO, ECUADOR.

e-mail: rscgtexcmex@hotmail.com 